\title{
Effect of propargylic substitution on the 5-endo-trig cyclization of bromomethyldimethylsilyl propargyl ethers
}

\author{
Stéphane Bogen, Jean-Philippe Goddard, Louis Fensterbank, and Max Malacria* \\ UPMC Univ Paris 06, Laboratoire de Chimie Organique (UMR CNRS 7611), Institut de Chimie \\ Moléculaire (FR 2769), case 229, 4, place Jussieu, 75252 Paris cedex 05, France \\ E-mail: louis.fensterbank@upmc.fr, max.malacria@upmc.fr
}

Dedicated to Professor Arlette Solladie-Cavallo on the occasion of her $\mathbf{7 0}^{\text {th }}$ anniversary

\begin{abstract}
A radical cascade reaction involving bromomethyldimethylsilyl propargyl ethers is described. The constituent steps of this cascade are a 5-exo-dig cyclization, a 1,5-H transfer and a final 5-endo-trig radical process leading to the diastereoselective formation of functionalized cyclopentanol derivatives. The influence of propargylic substitution has been studied. Increasing the size of the propargylic substituents favors the 5-endo-trig cyclization process. In addition, bicyclic [4.3.0] and [3.3.0] derivatives have been prepared as single diastereoisomers.
\end{abstract}

Keywords: Bromomethyldimethylsilyl propargyl ethers, 5-endo-trig radical cyclization, 1,5-H transfer, radical cascade, diastereoselective cyclization, polysubstituted cyclopentanol

\section{Introduction}

Over the last decade, the 5-endo-trig radical cyclization has received intense attention of the community of radical chemists. ${ }^{1}$ Despite being disfavored according to Balwin's rules, ${ }^{2}$ several efficient processes have now been devised, ${ }^{3}$ most of them including heteroatoms in the tethers. ${ }^{4}$ Recently, the mechanism of this process has been addressed computationally and it was concluded that "In the absence of steric or conformational effects, the endo cyclization to form the five-membered ring was strongly favored over exo cyclization to form the four-membered ring not only on thermodynamic grounds but also kinetically". ${ }^{5}$ This justifies the large number of reports nowadays of 5-endo-trig cyclizations and also sets the stage for further developments. 


\section{Results and Discussion}

In the course of our studies on the radical cyclization of propargylic bromomethyldimethylsilyl ethers, ${ }^{6}$ we have stumbled into the endo- mode of cyclization while examining the behavior of di-isopropyl precursors of type 1. $^{7}$ Thus, when submitted to typical radical reactions conditions, the initial $\alpha$-silyl radical undergoes a 5-exo-dig cyclization to generate a vinyl radical that exists in two forms as $E-4$ or $Z-4$. The $E$ vinyl radical intermediate displays a severe 1,3 allylic

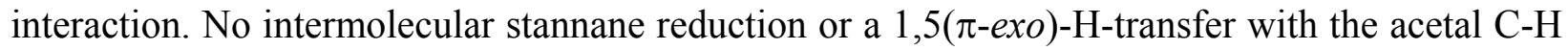
activated bond intervenes so that the equilibrium is shifted towards the $Z-4$ vinyl radical. Only the staggered Z-4st vinyl radical undergoes a remarkably chemoselective $1,5-\mathrm{H}$ transfer with a nonactivated $\mathrm{C}-\mathrm{H}$ bond. Indeed, this diastereoselective 1,5( $\pi$-endo)-H takes place such that it minimizes the interaction between the methyl and the isopropyl group: eclipsed Z-4ec versus staggered Z-4st.

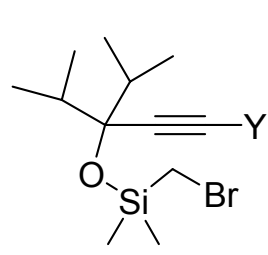

$1 a$
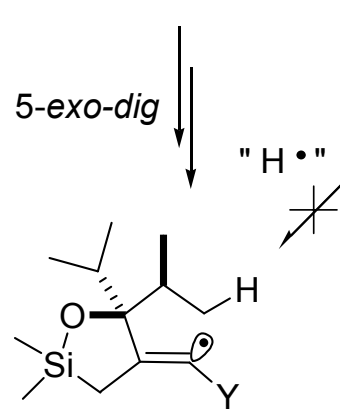

Z-4st

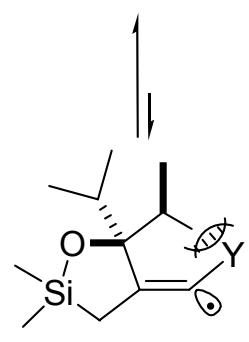

E-4
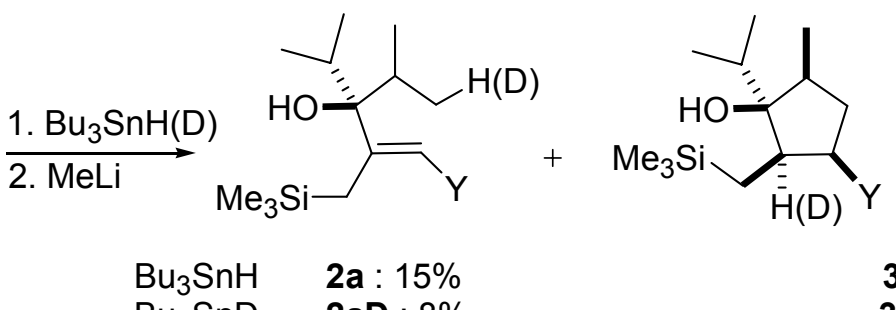

2a : $15 \%$

2aD : $8 \%$


3a : $74 \%$

3aD : $74 \%$<smiles>CC(C)(C)[18O][13CH2]</smiles>

$1,5-\mathrm{H}$

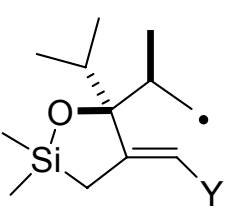

5

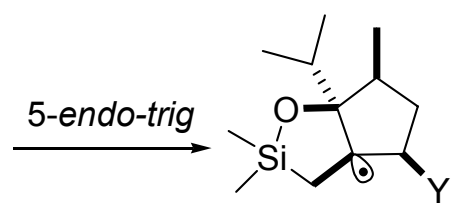

6<smiles>[Y]=C[CH]C(=[V])C1OCCO1</smiles>

Scheme 1. Behavior of di-isopropyl derivative under radical conditions. 
Moreover, no deuterium was incorporated into the vinyl moiety of 2, suggesting complete hydrogen transfer. In this particular step the stereochemistry of the double bond $(Z)$ as well as two new stereogenic centers are set. The resulting methylene radical $\mathbf{5}$ can be reduced to furnish $\mathbf{2 a}$ or can then cyclize via a disfavored 5-endo-trig mode, placing the dioxolanyl chain syn to the methyl group and to the $\mathrm{C}-\mathrm{O}$ bond. A diastereoselective stannane reduction of the $\beta$-silyl radical 6 installs a cis ring juncture and terminates the sequence. The proposed relative stereochemistry of the four new stereogenic centers was confirmed by an X-ray crystallographic determination of the cyclopentanediol derivative obtained after a Tamao oxidation of the corresponding

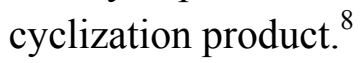

Variations around the acetylenic Y groups including sulfur and phosphorus groups have been reported, ${ }^{9}$ and herein, we pursue our analysis of the scope and limitations of this process, in particular by introducing less sterically demanding groups at the propargylic position. A new set of precursors has been prepared, using straightforward chemistry.

A general pathway is reported highlighting the different products obtained under radical conditions (Scheme 2). We report only the compounds isolated after nucleophilic treatment of the cyclic silyl ether but a Tamao oxidation allowed the generation of the corresponding diol. ${ }^{9}$ Three structurally and functionally different products were usually isolated resulting from three radical pathways. The chemical yields of those derivatives are representative of their respective abundance in the reaction mixture. Allylsilane $\mathbf{2}$ can be obtained through two pathways. The first one involves an early reduction of radical 7, explaining the deuterium incorporation into a methyl group when the reaction is conducted in the presence of tributyltin deuteride. A second 1,5-H transfer affording $\beta$-silyl and allylic radical $\mathbf{8}$ would also give $\mathbf{2}$ after reduction at the $\alpha$ silyl position on $8 .{ }^{10}$ Alternatively, allylic radical can be reduced at the exocyclic position providing the vinylsilane 9. As previously reported, the cyclopentyl derivative 3 is formed by a 5-endo-trig cyclization process and a reduction of the resulting tertiary radical.

When the two isopropyl groups were replaced by a single tert-butyl group, a dramatic decrease of the cyclic compound yield was recorded, with only $14 \%$ of $\mathbf{3 b}$ being isolated (entry 1, Table 1). The olefinic derivatives were isolated in $22 \%(\mathbf{2 b})$ and $51 \%(\mathbf{9 b})$. The presence of a tertiary propargylic center does not seem to be sufficient to promote the cyclization even with a Thorp-Ingold effect from the gem-dimethyl substitution. The radical cyclization of the iso-butyl precursor 1c yielded only the olefinic product 2c (entry 2, Table 1). The deuterium was incorporated at the isopropyl position, resulting from the usual 1,5-H transfer. This rather stabilized tertiary radical did not undergo any 5-endo-trig or double 1,5-H transfer. The same result ( $80 \%$ of $\mathbf{2 d}$ ) was confirmed with the benzyl precursor 1d (entry 3, Table 1), confirming that secondary or tertiary radicals are also reluctant to undergo an additional 1,5 transfer, probably because of steric interaction with the gem-dimethylsilyl groups, and to cyclize into a 5-endo-trig mode. 


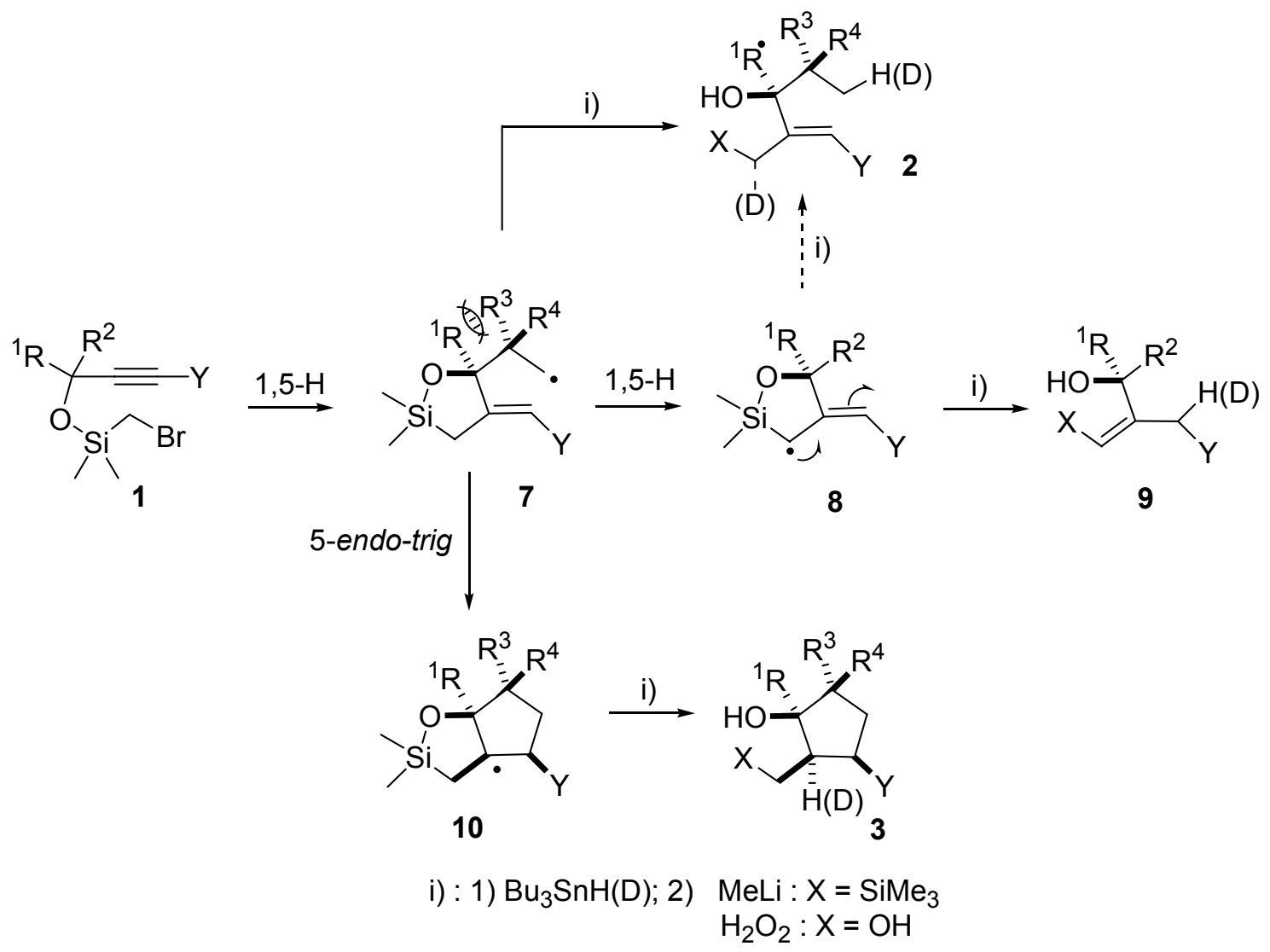

Scheme 2. Influence of the propargylic substitution.

Table 1. Radical reaction of mono-substituted compound at the propargylic position

Entry Substrate

${ }^{\mathrm{a}}$ See ref. 7. 
The di-isopropyl group was then replaced by a gem-diethyl group (compound $\mathbf{1 h}$ ) and the behavior of the radical reaction was explored (entry 4, Table 2). Here also, the gem-diethyl group hinders any intermolecular reduction. No intermolecular trapping of the vinyl radical was observed with $\mathrm{Bu}_{3} \mathrm{SnD}$ and the 1,5-H transfer is complete. Direct bimolecular reduction of the methylene radical is observed $(\mathbf{2 h})$. However, the 5-endo-trig cyclization leading to $\mathbf{3 h}$ becomes a minor process at the expense of the double 1,5-H transfer process. This allyl radical is mainly reduced at the exocyclic position (39\% of $9 \mathbf{h})$. The proportion of 5-endo-trig closure decreased in favor of the double 1,5-H shift, as if the steric bulk of the propargylic substituents was the determining factor for the pent-4-enyl radical to undergo this cyclization. This would be consistent with a particularly congested transition state in the case of the di-isopropyl group, in which the 5-endo-trig cyclization appears as the main way out for the methylene radical. By lightening the steric bulk, more opportunities are now open for the methylene radical: intermolecular reduction, double 1,5-H transfer and 5-endo-trig.

To assess further requirements for 5-endo-trig cyclization, we studied precursors bearing one isopropyl group and a different group at the propargylic position (Table 2). We anticipated that a repulsion effect between the two substituents should modify the angle of attack of the 4-pentenyl radical, and restore the efficiency of 5-endo-trig cyclization.

Table 2. Radical reaction of di-substituted compound at the propargylic position

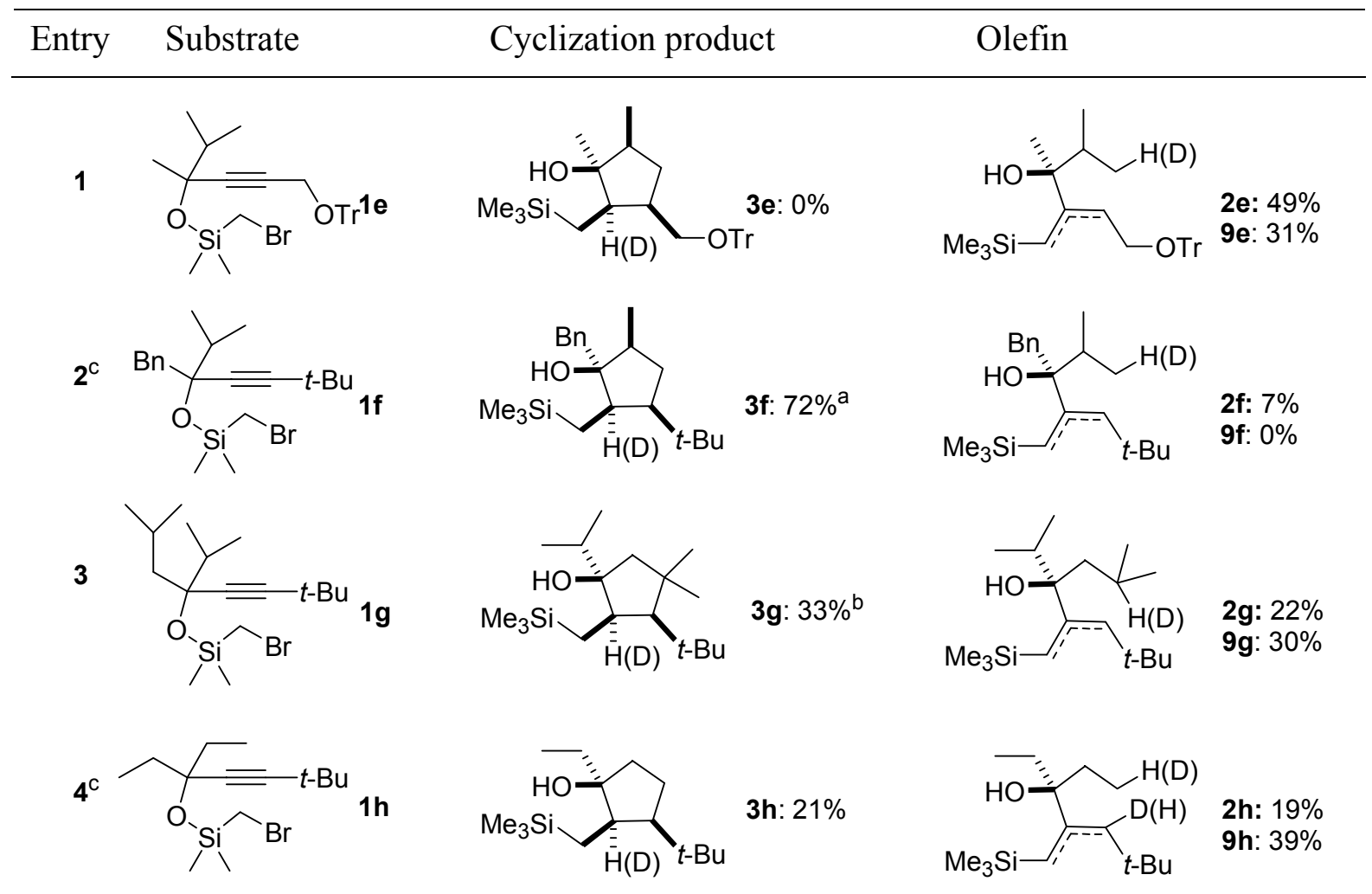

${ }^{\mathrm{a}} 4 \%$ of a second diastereomer (presumably epimer at the methyl substituted center). ${ }^{\mathrm{b}}$ Mixture of products: $13 \%$ of $\mathbf{3 g}$ and $20 \%$ of the corresponding vinylsilane. ${ }^{\mathrm{c}}$ See ref. 7 . 
In order to gain insight into the importance of the double substitution at the propargylic position, the compound 1e with a methyl and an isopropyl groups was studied (entry 1, Table 2). The isopropyl group would be able to promote the 1,5-H transfer and the methyl group would generate the supposed important steric repulsion between these two groups. Unfortunately, in the presence of tin hydride, the cyclization adduct $\mathbf{3 e}$ was not isolated and only $\mathbf{2 e}$ and $\mathbf{9 e}$ were formed in $49 \%$ and $31 \%$ yields respectively. Thus, these two groups are not sufficient for a 5-endo-trig process. The methyl group was then replaced by the more sterically demanding benzyl group (entry 2, Table 2). Under the same conditions, compound $\mathbf{1 f}$ allowed the formation of cyclized adduct $\mathbf{3 f}$ in $72 \%$ yield. In this case, $4 \%$ of a second diastereoisomer was detected in contrast to the di-isopropyl substrate. It has to be noted that no double 1,5-H transfer adduct 9f was detected in this reaction and only $7 \%$ of $\mathbf{2 f}$ was formed. When the benzyl group was replaced by an isobutyl group (compound 1g, entry 3, Table 2), the efficiency of the 5-endo-trig process decreased and 33\% of cyclic compound $\mathbf{3 g}$ was isolated as a mixture with an exocyclic vinylsilane resulting from a $\beta$-elimination. ${ }^{7}$ The structures of the isolated products and the deuteration experiments showed that the $1,5-\mathrm{H}$ transfer is completely chemoselective towards the formation of the more stable tertiary radical. The formation of this hindered radical could explain the lower efficiency of the cyclization reaction.

Regarding scope for the formation of polycyclic compounds, it appeared to be interesting to check the influence of having a cyclic template at the propargylic position on the 5-endo-trig process. Three different substrates were prepared and the corresponding radical reactions were carefully studied (Table 3).

Table 3. Formation of bicyclic derivatives

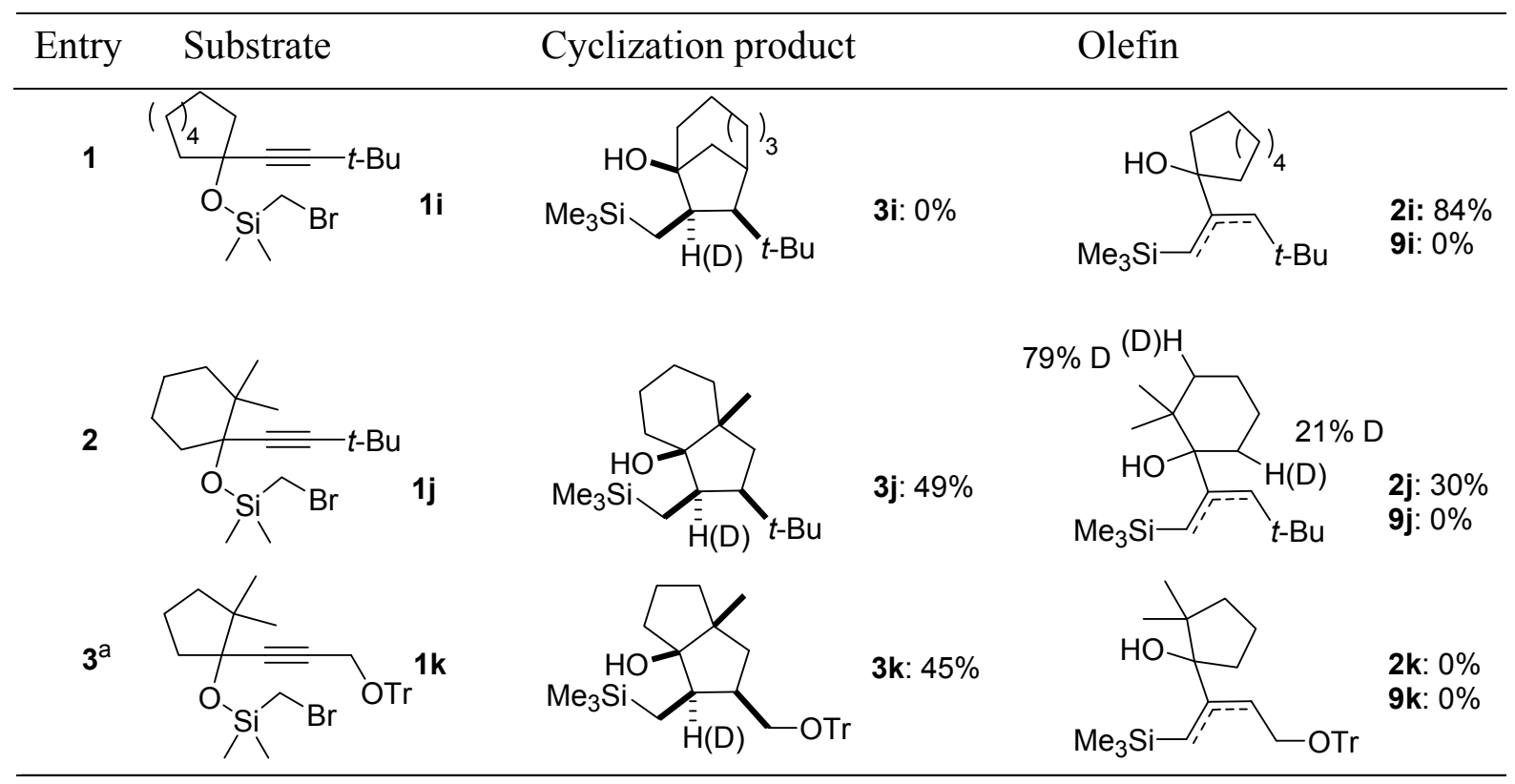

${ }^{\mathrm{a}}$ See ref.7. 
Cyclooctyl derivative $\mathbf{1 i}$ did not lead to formation of bicyclic adduct $\mathbf{3 i}$ and only allysilane $\mathbf{2 i}$ was observed in $84 \%$ yield (entry 1 , Table 3 ). The 5-endo-trig process seems to be inefficient when the radical is generated in a preformed ring. gem-Dimethyl substituted cyclohexyl $\mathbf{1} \mathbf{j}$ and cyclopentyl $\mathbf{1 k}$ derivatives gave similar results with the formation of bicyclic compounds $\mathbf{3} \mathbf{j}$ and 3k in $49 \%$ and $45 \%$ yield respectively as single diastereoisomers (entries 2 and 3, Table 3). ${ }^{11}$ Uncyclized adduct $\mathbf{2} \mathbf{j}$ was obtained in $30 \%$ yield. The same reaction with $\mathrm{Bu}_{3} \mathrm{SnD}$ instead of $\mathrm{Bu}_{3} \mathrm{SnH}$ showed two sites of deuterium incorporation. The diastereoselectivity and the deuterium distribution can be explained based on two transitions states (Scheme 3).

A

B

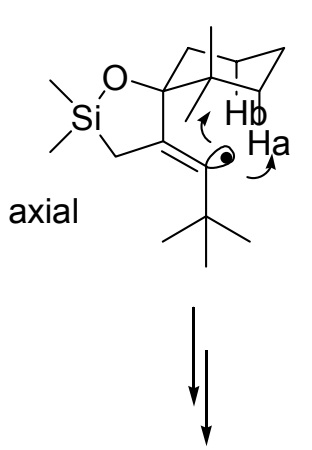

2j
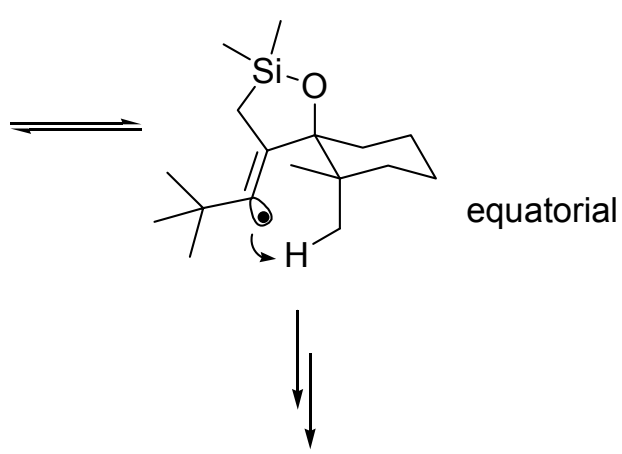

3j

Scheme 3. Explanation of diastereoselectivity and deuterium distribution.

When the conformation of the cyclohexyl moiety leads to the vinylic radical in an equatorial position (B), only one hydrogen is in the correct position for the $H$ transfer. The subsequent exocyclic radical can directly cyclize following the observed diastereoselectivity. When the vinylic radical is in an axial position $(\mathbf{A})$, two of the hydrogen atoms ( $\mathrm{Ha}$ and $\mathrm{Hb}$ ) of the cyclohexyl group are well-positioned for the abstraction. Ha-transfer is favored due to the steric repulsion between the gem-dimethyl group and the heterocycle that would arise in the transitionstate leading to Hb-transfer.

In conclusion, the substitution of the propargylic position seems to be very important for the behavior of the radical reaction. A mono-substitution does not induce sufficient steric repulsion to promote the 5-endo-trig cyclization process. When a second substituent is introduced in this position, it can increase the efficiency of this cyclization leading to the diastereoselective formation of cyclopentyl derivatives. Bicyclic products can also be obtained in moderate yield from a gem-dimethyl substituted cyclic template. 


\section{Experimental Section}

General Procedures. All reactions were performed under an argon or nitrogen atmosphere in anhydrous solvents and dried flasks. Thin layer chromatography (TLC) was performed on Merck silica gel $60 \mathrm{~F} 254$ and revealed with either an ultraviolet lamp $(\lambda=254 \mathrm{~nm})$ or a $p$-anisaldehyde solution. Flash column chromatography was performed with silica gel (Merck Geduran SI, 40-63 $\mathrm{nm})$. Solvents were distilled prior use. IR spectra were recorded on a Perkin-Elmer 1420 spectrometer and on a Bruker Tensor 27. ${ }^{1} \mathrm{H}$ and ${ }^{13} \mathrm{C}$ NMR spectra were recorded at $400 \mathrm{MHz}$ and $100 \mathrm{MHz}$ respectively on an ARX400 Bruker spectrometer. Shifts are given in ppm and referenced from the solvent residual signal $\left(7.26 \mathrm{ppm}\right.$ for $\mathrm{CDCl}_{3}$ ) for proton NMR. For carbon NMR, shifts are referenced from the solvent central peak (77.3 ppm for $\mathrm{CDCl}_{3}$ ). Coupling constants $(J)$ are given in Hertz $(\mathrm{Hz})$. The letters $\mathrm{m}, \mathrm{s}, \mathrm{d}$, t, q, sept mean respectively multiplet, singlet, doublet, triplet, quartet, septet. Specific rotations were measured on a Perkin Elmer 343 polarimeter. Elemental analyses were performed by the Service Régional de Microanalyse de l'Université Pierre et Marie Curie. Melting points were obtained on a Reichert apparatus and are uncorrected. EE is for Ethyl Ether.

Compounds $\mathbf{1 b}, \mathbf{1 f}, \mathbf{1 h}$ and $\mathbf{1 k}$ have been previously reported, as well as the corresponding radical cyclization derivatives and the preparation of $\mathbf{1 c}, \mathbf{1 d}, \mathbf{1 e}, \mathbf{1 g}, \mathbf{1 i}$ and $\mathbf{1 j}$ followed the same general procedure. ${ }^{7,9}$

Typical procedure for the radical cyclization of bromomethyldimethylsilyl propargyl ether A benzene solution $(13.5 \mathrm{~mL})$ of $\mathrm{Bu}_{3} \mathrm{SnH}(360 \mu \mathrm{L}, 1.34 \mathrm{mmol})$ containing AIBN (30 mg, 0.18 mmol) was added by a syringe pump over a period of $6.5 \mathrm{~h}\left(2.10^{-4} \mathrm{~mol}^{-1}\right)$ to a solution of $1(1.0$ mmol) and AIBN (10 mg, $0.06 \mathrm{mmol})$ in refluxing benzene $(40 \mathrm{~mL})$ under argon. After completion of the addition, the mixture was allowed to reflux for an additional $2 \mathrm{~h}$. A subsequent nucleophilic substitution with methyllithium led to the formation of the corresponding derivatives. $^{7,9}$

1-Bromomethyldimethylsilyloxy-1-isobutyl-4-triphenylmethyloxybut-2-yne (1c). Gummy solid. $\mathrm{Rf}=0.46$ (95/5 : petroleum ether/EE). IR (film) : 3020, 2970, 1580, 1480, 1440, 1360, 1250, 1150, 1070, 830, $700 \mathrm{~cm}^{-1} \cdot{ }^{1} \mathrm{H}$ NMR $\left(200 \mathrm{MHz}, \mathrm{CDCl}_{3}\right) \delta 7.52-7.23(15 \mathrm{H}, \mathrm{m}), 4.55(1 \mathrm{H}$, $J=6.5$ et $1.3 \mathrm{~Hz}, \mathrm{tt}), 3.79(2 \mathrm{H}, J=1.3 \mathrm{~Hz}, \mathrm{~d})), 2.75-2.59\left(2 \mathrm{H}, \mathrm{m}_{\mathrm{AB}}\right), 1.83(1 \mathrm{H}, J=6.6 \mathrm{~Hz}$, sept), $1.67-1.53(2 \mathrm{H}, \mathrm{m}), 0.94(6 \mathrm{H}, J=6.6 \mathrm{~Hz}, \mathrm{~d}), 0.40(6 \mathrm{H}, \mathrm{s}) .{ }^{13} \mathrm{C} \mathrm{NMR}\left(50 \mathrm{MHz}, \mathrm{CDCl}_{3}\right) \oint-2.5,-$ $2.3,16.7,22.4,22.8$. 24.5, 47.4, 53.3, 62.0, 81.7, 86.8, 87.5, 127.3 (3C), 128.1 (6C), 128.7 (6C), $143.6(3 \mathrm{C})$.

1-Bromomethyldimethylsilyloxy-4,4-dimethyl-1-(2-phenylethyl)pent-2-yne (1d). Colorless oil. $\mathrm{Rf}=0.54$ (95/5 : petroleum ether/EE). IR (film) : 3030, 3010, 2960, 1590, 1480, 1450, 1340, 1250, 840, $690 \mathrm{~cm}^{-1} .{ }^{1} \mathrm{H}$ NMR $\left(200 \mathrm{MHz} \mathrm{CDCl}_{3}\right) \delta 7.30-7.20(5 \mathrm{H}, \mathrm{m}), 4.41(1 \mathrm{H}, J=6.4 \mathrm{~Hz}, \mathrm{t})$, $2.76(2 \mathrm{H}, J=7.6 \mathrm{~Hz}, \mathrm{t}), 2.59(2 \mathrm{H}, \mathrm{s}), 2.03-1.94(2 \mathrm{H}, \mathrm{m}), 1.25(9 \mathrm{H}, \mathrm{s}), 0.36(3 \mathrm{H}, \mathrm{s}), 0.35(3 \mathrm{H}, \mathrm{s})$.

${ }^{13} \mathrm{C} \mathrm{NMR}\left(50 \mathrm{MHz}, \mathrm{CDCl}_{3}\right) \oint-2.3,-2.2,16.7,27.5,31.0(3 \mathrm{C}), 31.7,40.5 .62 .9,79.6,94.3,126.0$, 128.5 (2C), $128.6(2 \mathrm{C}), 141.8$. 
1-Bromomethyldimethylsilyloxy-1-isopropyl-1-methyl-4-triphenylmethoxybut-2-yne (1e). Gummy solid. Rf= 0.40 (95/5 : petroleum ether/EE). IR (film): 3050, 2960, 1580, 1480, 1370, 1250, 1050, 850, $700 \mathrm{~cm}^{-1} .{ }^{1} \mathrm{H}$ NMR $\left(400 \mathrm{MHz}, \mathrm{CDCl}_{3}\right) \delta 7.55-7.28(15 \mathrm{H}, \mathrm{m}), 3.84(2 \mathrm{H}, \mathrm{s})$, 2.80-2.71 (2H, m $\mathrm{AB}), 1.84(1 \mathrm{H}, J=6.7 \mathrm{~Hz}, \mathrm{sept}), 1.47(3 \mathrm{H}, \mathrm{s}), 1.05(3 \mathrm{H}, J=6.7 \mathrm{~Hz}, \mathrm{~d}), 1.02(3 \mathrm{H}$, $J=6.7 \mathrm{~Hz}, \mathrm{~d}), 0.49(3 \mathrm{H}, \mathrm{s}), 0.48(3 \mathrm{H}, \mathrm{s}) .{ }^{13} \mathrm{C} \mathrm{NMR}\left(50 \mathrm{MHz}, \mathrm{CDCl}_{3}\right) \delta-0.9(2 \mathrm{C}), 17.7,17.8$, 18.1, 28.5. 40.0 53.4, 73.7, 82.2, 87.6, 88.5, 127.3 (3C), 128.1 (6C), 128.7 (6C), 143.,6 (3C).

1-Bromomethyldimethylsilyloxy-1-isobutyl-1-isopropyl-4,4-dimethylpent-2-yne (1g). Colorless oil. $\mathrm{Rf}=0.70$ (95/5 : petroleum ether/EE). IR (film): 2960, 2220, 1460, 1250, 1050, $840 \mathrm{~cm}^{-1} .{ }^{1} \mathrm{H}$ NMR $\left(400 \mathrm{MHz}, \mathrm{CDCl}_{3}\right) \oint 2.66-2.60\left(2 \mathrm{H}, \mathrm{m}_{\mathrm{AB}}\right), 1.90-1.81(2 \mathrm{H}, \mathrm{m}), 1.58-1.41$ $\left(2 \mathrm{H}, \mathrm{m}_{\mathrm{ABX}}\right), 1.24(9 \mathrm{H}, \mathrm{s}), 1.00-0.92(12 \mathrm{H}, \mathrm{m}), 0.37(3 \mathrm{H}, \mathrm{s}), 0.36(3 \mathrm{H}, \mathrm{s}) .{ }^{13} \mathrm{C} \mathrm{NMR}(100 \mathrm{MHz}$, $\left.\mathrm{CDCl}_{3}\right): \delta-0.9(2 \mathrm{C}), 17.7,17.8 ; 18.0,24.2,24.5,24.9,27.5,30.9$ (3C), 37.8, 48.2, 76.5, 81.7, 94.6.

1-Bromomethyldimethylsilyloxy-1-(3,3-dimethyl-1-butynyl)-1-cyclooctane (1i). Colorless oil. $\mathrm{Rf}=0.60$ (95/5 : petroleum ether/EE). IR (film) : 3010, 2960, 2220, 1590, 1490, 1380, 1250, $1070,850 \mathrm{~cm}^{-1} .{ }^{1} \mathrm{H}$ NMR $\left(400 \mathrm{MHz}, \mathrm{CDCl}_{3}\right) \oint 7.33-7.30(5 \mathrm{H}, \mathrm{m}), 2.92-2.81\left(2 \mathrm{H}, \mathrm{m}_{\mathrm{AB}}\right), 2.49-$ $2.06\left(2 \mathrm{H}, \mathrm{m}_{\mathrm{AB}}\right), 1.87(1 \mathrm{H}, J=6.8 \mathrm{~Hz}$, sept $), 1.26(9 \mathrm{H}, \mathrm{s}), 1.08(3 \mathrm{H}, J=6.8 \mathrm{~Hz}, \mathrm{~d}), 1.07(3 \mathrm{H}, J=$ $6.8 \mathrm{~Hz}, \mathrm{~d}), 0.15(3 \mathrm{H}, \mathrm{s}), 0.12(3 \mathrm{H}, \mathrm{s}) .{ }^{13} \mathrm{C} \mathrm{NMR}\left(50 \mathrm{MHz}, \mathrm{CDCl}_{3}\right) \delta-1.5,-1.4,18.1(2 \mathrm{C}), 17.8$, 27.6, 30.9 (3C), 39.9, 45.8, 76.7, 80.2, 96.4, 126.6, 127.6 (2C), 131.6 (2C). 137.6. Anal. Calc. for $\mathrm{C}_{17} \mathrm{H}_{31} \mathrm{OSiBr}$ : $56.81, \mathrm{H}$ 8.69. Found: C 56.74, H 8.76.

\section{1-Bromomethyldimethylsilyloxy-1-(3,3-dimethyl-1-butynyl)-2,2-dimethyl-1-cyclohexane}

(1j). Colorless oil. $\mathrm{Rf}=0.70$ (95/5 : petroleum ether/EE). IR (film) : 2970, 2220, 1450, 1250, 1080, 1050, $840 \mathrm{~cm}^{-1} .{ }^{1} \mathrm{H}$ NMR $\left(400 \mathrm{MHz}, \mathrm{CDCl}_{3}\right) \oint 2.65-2.59\left(2 \mathrm{H}, \mathrm{m}_{\mathrm{AB}}\right), 1.71(2 \mathrm{H}, J=6.1 \mathrm{~Hz}$, t), 1.62-1.34 (6H, m), $1.26(9 \mathrm{H}, \mathrm{s}), 1.01(3 \mathrm{H}, \mathrm{s}), 0.95(3 \mathrm{H}, \mathrm{s}), 0.36(3 \mathrm{H}, \mathrm{s}), 0.34(3 \mathrm{H}, \mathrm{s}) .{ }^{13} \mathrm{C}$ NMR (50 MHz, $\left.\mathrm{CDCl}_{3}\right) \delta$-1.0 (2C), 17.9, 21.3, 22.6, 22.9, 25.4, 27.5, 31.0 (3C), 35.9, 37.1. 38.8, 75.6, 81.7, 95.0. Anal. Calc. for $\mathrm{C}_{17} \mathrm{H}_{31} \mathrm{OSiBr}$ : C 56.81 H 8.69. Found: C 56.91 H 8.75.

1-Isobutyl-2-trimethylsilylmethyl-4-triphenylmethyloxy-(Z)-but-2-en-1-ol (2c). Colorless oil. $\mathrm{Rf}=0.26$ (80/20 : petroleum ether/EE). IR (film) : 3590, 3030, 2970, 1650, 1580, 1490, 1440, 1220, 1040, 850, $690 \mathrm{~cm}^{-1} .{ }^{1} \mathrm{H}$ NMR $\left(200 \mathrm{MHz}, \mathrm{CDCl}_{3}\right) \delta$ 7.61-7.27 (15H, m), $5.78(1 \mathrm{H}, J=6.1$ $\mathrm{Hz}, \mathrm{t}), 4.17-4.05(1 \mathrm{H}, \mathrm{m}), 3.67(2 \mathrm{H}, J=6.1 \mathrm{~Hz}, \mathrm{~d}), 1.96-1.85(1 \mathrm{H}, \mathrm{m}), 1.64-1.49(2 \mathrm{H}, \mathrm{m}), 1.46-$ $1.28\left(2 \mathrm{H}, \mathrm{m}_{\mathrm{AB}}\right), 1.07(3 \mathrm{H}, J=6.4 \mathrm{~Hz}, \mathrm{~d}), 1.04(3 \mathrm{H}, J=6.4 \mathrm{~Hz}, \mathrm{~d}),-0.5(9 \mathrm{H}, \mathrm{s}) .{ }^{13} \mathrm{C}$ NMR $(50$ $\left.\mathrm{MHz}, \mathrm{CDCl}_{3}\right) \delta$ - -0.5 (3C), 19.2, 22.0, 23.8, 25.0, 45.4, 61.7, 74.3, 86.6, 118.3, 127.0 (3C), 127.9 (6C), 128.8 (6C), 144.1, 144.5 (3C). Anal. Calc. for $\mathrm{C}_{31} \mathrm{H}_{40} \mathrm{O}_{2} \mathrm{Si}$ : C 78.76, $\mathrm{H}$ 8.53. Found: C $78.69, \mathrm{H} 8.50$.

1-(2-Deutero-2-methylpropyl)-2-trimethylsilylmethyl-4-triphenylmethyloxy-( $Z$ )-but-2-en-1ol (2cD). Gummy solid. $\mathrm{Rf}=0.26$ (80/20 : petroleum ether/EE). IR (film) : 3590, 3030, 2970, 1650, 1580, 1490, 1440, 1220, 1040, 850, $690 \mathrm{~cm}^{-1} .{ }^{1} \mathrm{H}$ NMR (400 MHz, $\left.\mathrm{CDCl}_{3}\right) \oint 7.61-7.22$ $(15 \mathrm{H}, \mathrm{m}), 5.79(1 \mathrm{H}, J=6.1 \mathrm{~Hz}, \mathrm{t}), 4.12-4.06(1 \mathrm{H}, \mathrm{m}), 3.67(2 \mathrm{H}, J=6.2 \mathrm{~Hz}, \mathrm{~d}), 1.62-1.45(2 \mathrm{H}$, $\mathrm{m}), 1.41-1.28\left(2 \mathrm{H}, \mathrm{m}_{\mathrm{AB}}\right), 1.06(3 \mathrm{H}, \mathrm{s}), 1.04(3 \mathrm{H}, \mathrm{s}),-0.4(9 \mathrm{H}, \mathrm{s}) .{ }^{13} \mathrm{C} \mathrm{NMR}\left(50 \mathrm{MHz}, \mathrm{CDCl}_{3}\right) \delta$ 0.5 (3C), 19.1, 21.9, 23.7, 24.6 (t, $J=20 \mathrm{~Hz}, \mathrm{CD}), 45.3,61.7,74.2,86.8,118.2,127.0$ (3C), 127.9 (6C), 128.8 (6C), 144.1, $144.5(3 \mathrm{C})$. 
1-(2-Phenylethyl)-2-trimethylsilylmethyl-4,4-dimethyl-( $Z$ )-pent-2-en-1-ol (2d). Colorless oil. $\mathrm{Rf}=0.28$ (85/15 : petroleum ether/EE). IR (film) : 3460, 3030, 3010, 2970, 1640, 1600, 1480, 1350, 1150, 840, $700 \mathrm{~cm}^{-1} .{ }^{1} \mathrm{H}$ NMR (200 MHz, $\left.\mathrm{CDCl}_{3}\right) \oint 7.31-7.13(5 \mathrm{H}, \mathrm{m}), 5.33(1 \mathrm{H}, \mathrm{s}), 3.86-$ $3.78(1 \mathrm{H}, \mathrm{m}), 2.76-2.58(2 \mathrm{H}, \mathrm{m}), 1.87-1.74(2 \mathrm{H}, \mathrm{m}), 1.51-1.30\left(2 \mathrm{H}, \mathrm{m}_{\mathrm{AB}}\right), 1.10(9 \mathrm{H}, \mathrm{s}), 0.01(9 \mathrm{H}$, s). ${ }^{13} \mathrm{C} \mathrm{NMR}\left(50 \mathrm{MHz}, \mathrm{CDCl}_{3}\right) \delta-0.1(3 \mathrm{C}), 18.9,31.4(3 \mathrm{C}), 32.1,32.3,37.9,76.7,125.7,128.3$ (2C), 128.5 (2C), 132.0, 139.0, 142.2.

3,4-Dimethyl-1-trimethylsilyl-2-(2-triphenylmethyloxyethyl)-(Z)-pent-1-en-3-ol

(9e). Gummy solid. $\mathrm{Rf}=0,46$ (85/15 : petroleum ether/EE). IR (film) : 3500, 2970, 1600, 1580, 1490, 1470, 1240, 1040, 850, $690 \mathrm{~cm}^{-1} .{ }^{1} \mathrm{H}$ NMR (400 MHz, $\left.\mathrm{CDCl}_{3}\right) \delta .51-7.25(15 \mathrm{H}, \mathrm{m}), 5.24(1 \mathrm{H}$, s), $3.29(2 \mathrm{H}, J=6.5 \mathrm{~Hz}, \mathrm{t}), 2.31(2 \mathrm{H}, J=6.5 \mathrm{~Hz}, \mathrm{t}), 1.92-1.87(1 \mathrm{H}, \mathrm{m}), 1.26(3 \mathrm{H}, \mathrm{s}), 0.95(3 \mathrm{H}, J=$ $6.7 \mathrm{~Hz}, \mathrm{~d}), 0.74(3 \mathrm{H}, J=6.7 \mathrm{~Hz}, \mathrm{~d}), 0.11(9 \mathrm{H}, \mathrm{s}) .{ }^{13} \mathrm{C} \mathrm{NMR}\left(50 \mathrm{MHz}, \mathrm{CDCl}_{3}\right) \delta 2.5(3 \mathrm{C}), 16.2$, 17.6, 26.5, 33.7, 63.6, 35.0, 79.6, 86.8, 122.9, 121.7 (3C), 127.9 (6C), 128.9 (6C), 144.6 (3C), 160.2 .

1-Isopropyl-1-methyl-2-trimethylsilylmethyl-4-triphenylmethyloxy-(Z)-but-2-en-1-ol (2e). Gummy solid. $\mathrm{Rf}=0.28$ (85/15 : petroleum ether/EE). IR (film) : 3550, 3030, 2970, 1650, 1580, 1490, 1470, 1220, 1040, 850, $690 \mathrm{~cm}^{-1} .{ }^{1} \mathrm{H}$ NMR (200 MHz, $\left.\mathrm{CDCl}_{3}\right) \delta$ 7.47-7.17 (15H, m), 5.56 $(1 \mathrm{H}, J=6.0 \mathrm{~Hz}, \mathrm{t}), 3.54-3.47(2 \mathrm{H}, \mathrm{m}), 1.86(1 \mathrm{H}, J=6.8 \mathrm{~Hz}, \mathrm{sept}), 1.42-1.25\left(2 \mathrm{H}, \mathrm{m}_{\mathrm{AB}}\right), 1.24(3 \mathrm{H}$, s), $0.89(6 \mathrm{H}, J=6.8 \mathrm{~Hz}, \mathrm{~d}),-0.21(9 \mathrm{H}, \mathrm{s}) .{ }^{13} \mathrm{C} \mathrm{NMR}\left(50 \mathrm{MHz}, \mathrm{CDCl}_{3}\right) \oint 0.0(3 \mathrm{C}), 17.2,17.7$, $18.4,24.4,35.7,62.7,77.5,86.7,118.3,127.0$ (3C), 127.9 (6C), 128.8 (6C), 144.5 (3C), 146.0.

Mixture of 3-tert-butyl-1-isopropyl-2-trimethylsilylmethyl-4,4-dimethylcyclopentan-1-ol (6g) and 3-tert-butyl-1-isopropyl-2-(1-trimethyl-(Z)-methylidene)-4,4-dimethylcyclopentan1-ol (3g'). Colorless oil. IR (film) : 3600, 3500, 2970, 1605, 1450, 1360, 1240, 860, $830 \mathrm{~cm}^{-1} .{ }^{1} \mathrm{H}$ NMR $\left(200 \mathrm{MHz}, \mathrm{CDCl}_{3}\right) \delta 5.72(1 \mathrm{H}, J=2.5 \mathrm{~Hz}, \mathrm{~d}), 2.45-2.38(1 \mathrm{H}, \mathrm{m}), 2.01-1.42(8 \mathrm{H}, \mathrm{m}), 1.23$ $(3 \mathrm{H}, \mathrm{s}), 1.16(3 \mathrm{H}, \mathrm{s}), 1.12(9 \mathrm{H}, \mathrm{s}), 1.09(3 \mathrm{H}, \mathrm{s}), 1,07(9 \mathrm{H}, \mathrm{s}), 1.04(3 \mathrm{H}, \mathrm{s}), 0.90(6 \mathrm{H}, J=6.6 \mathrm{~Hz}$, d), 0.86-0.80 (2H, m), $0.76(6 \mathrm{H}, J=6.6 \mathrm{~Hz}, \mathrm{~d}), 0.17(9 \mathrm{H}, \mathrm{s}), 0.02(9 \mathrm{H}, \mathrm{s}) .{ }^{13} \mathrm{C} \mathrm{NMR}(50 \mathrm{MHz}$, $\left.\mathrm{CDCl}_{3}\right) \delta 0.0(3 \mathrm{C}), 1.8(3 \mathrm{C}), 14.5,16.4,17.0,17.4,18.7,25.3(2 \mathrm{C}), 29.1,30.6$ (3C), $31.4(3 \mathrm{C})$, 31.9, 32.1, 33.6, 34.6, 37.9, 39.9, 40.7, 45.4, 50.8, 53.6, 60.1, 66.8, 81.0, 82.0, 124.0, 168.6.

3-Isopropyl-5-methyl-2-neopentyl-1-trimethylsilyl-(Z)-hex-1-en-3-ol (9g). Colorless oil. Rf= 0.44 (98/2 : petroleum ether/AcOEt). IR (film) : 3600, 2960, 1600, 1460, 1240, $850 \mathrm{~cm}^{-1} .{ }^{1} \mathrm{H}$ NMR $\left(200 \mathrm{MHz}, \mathrm{CDCl}_{3}\right) \oint 5.91(1 \mathrm{H}, \mathrm{s}), 1.97-1.78\left(2 \mathrm{H}, \mathrm{m}_{\mathrm{ABX}}\right), 1.76-1.41(4 \mathrm{H}, \mathrm{m}), 1.05(9 \mathrm{H}, \mathrm{s})$, $0.94(3 \mathrm{H}, J=6.7 \mathrm{~Hz}, \mathrm{~d}), 0.90(3 \mathrm{H}, J=6.6 \mathrm{~Hz}, \mathrm{~d}), 0.85(3 \mathrm{H}, J=6.6 \mathrm{~Hz}, \mathrm{~d}), 0.66(3 \mathrm{H}, J=6.7 \mathrm{~Hz}$, d), $0.22(9 \mathrm{H}, \mathrm{s}) .{ }^{13} \mathrm{C} \mathrm{NMR}\left(50 \mathrm{MHz}, \mathrm{CDCl}_{3}\right) \delta 1.6(3 \mathrm{C}), 17.1,17.7,23.4,25.0,25.8 ; 30.4(3 \mathrm{C})$, $31.1,34.5,44.4,44.9,94.4,121.9,165.2$. Anal. Calc. for $\mathrm{C}_{18} \mathrm{H}_{38} \mathrm{OSi}$ : C 72.41, $\mathrm{H}$ 12.83. Found: $\mathrm{C}$ $72.53, \mathrm{H} 13.04$.

\section{1-Isobutyl-1-isopropyl-4,4-dimethyl-2-trimethylsilylmethyl-(Z)-pent-2-en-1-ol}

(2g). Colorless oil. $\mathrm{Rf}=0.36$ (98/2 : petroleum ether/AcOEt). IR (film) : 3610, 2970, 1630, 1460, 1240, 1060, $850 \mathrm{~cm}^{-1} .{ }^{1} \mathrm{H}$ NMR (200 MHz, $\left.\mathrm{CDCl}_{3}\right) \delta 4.99(1 \mathrm{H}, \mathrm{s}), 1.88-1.65$ (2H, m), 1.78-1.48 $\left(2 \mathrm{H}, \mathrm{m}_{\mathrm{AB}}\right), 1.50-1.24\left(2 \mathrm{H}, \mathrm{m}_{\mathrm{ABX}}\right), 1.11(9 \mathrm{H}, \mathrm{s}), 0.93(3 \mathrm{H}, J=6.4 \mathrm{~Hz}, \mathrm{~d}), 0.90(3 \mathrm{H}, J=6.6 \mathrm{~Hz}, \mathrm{~d})$, $0.87(3 \mathrm{H}, J=6.4 \mathrm{~Hz}, \mathrm{~d}), 0.85(3 \mathrm{H}, J=6.6 \mathrm{~Hz}, \mathrm{~d}), 0.06(9 \mathrm{H}, \mathrm{s}) .{ }^{13} \mathrm{C} \mathrm{NMR}\left(50 \mathrm{MHz}, \mathrm{CDCl}_{3}\right) \delta 0.6$ 
(3C), 17.0, 17.6, 18.6, 23.9, 24.7, 25.0, 31.5 (3C), 35.4, 32.4, 44.5, 81.3, 132.3, 138.8. Anal. Calc. for $\mathrm{C}_{18} \mathrm{H}_{38} \mathrm{OSi}$ : C 72.41, H 12.83. Found: C 72.48, H 12.93.

1-(3,3-Dimethyl-(Z)-1-butenyl-1-trimethylsilylmethyl)-1-cyclooctanol (2i). Colorless oil. $\mathrm{Rf}=$ 0.30 (96/4 : petroleum ether/EE). IR (film) : 3600, 2960, 1640, 1460, 1240, $850 \mathrm{~cm}^{-1} .{ }^{1} \mathrm{H}$ NMR $\left(400 \mathrm{MHz}, \mathrm{CDCl}_{3}\right) \delta 5.19(1 \mathrm{H}, \mathrm{s}), 1.87-1.81(2 \mathrm{H}, \mathrm{m}), 1.73(2 \mathrm{H}, \mathrm{s}), 1.70-1.45(12 \mathrm{H}, \mathrm{m}), 1.13(9 \mathrm{H}$, s), $0.07(9 \mathrm{H}, \mathrm{s}) .{ }^{13} \mathrm{C}$ NMR $\left(100 \mathrm{MHz}, \mathrm{CDCl}_{3}\right) \delta 0.7$ (3C), 17.8, $22.5(2 \mathrm{C}), 24.9,28.4(2 \mathrm{C}), 31.7$ (3C), 32.1, 35.7 (2C), 78.5, 131.0, 142.3. Anal. Calc. for $\mathrm{C}_{18} \mathrm{H}_{36} \mathrm{OSi}$ : C 72.90, H 12.24. Found: C 73.01, H 12.28.

2-tert-Butyl-3-trimethylsilylmethyl-7a-methylperhydro-3a-indenol (3j). Colorless oil. $\mathrm{Rf}=$ 0.24 (85/15 : petroleum ether/ $\mathrm{CH}_{2} \mathrm{Cl}_{2}$ ). IR (film) : 3500, 2960, 1460, 1340, 1240, 1070, $830 \mathrm{~cm}^{-1}$. ${ }^{1} \mathrm{H}$ NMR $\left(400 \mathrm{MHz}, \mathrm{CDCl}_{3}\right) \oint 2.58(1 \mathrm{H}, J=10.7,7.6,3.1 \mathrm{~Hz}, \mathrm{ddd}), 2.05(1 \mathrm{H}, J=10.7,10,2 \mathrm{~Hz}$, dt), 1.65-1.24 (10H, m), $1.04(3 \mathrm{H}, \mathrm{s}), 1.00(1 \mathrm{H}, J=15.7 \mathrm{~Hz}, \mathrm{~d}), 0.98(9 \mathrm{H}, \mathrm{s}), 0.57(1 \mathrm{H}, J=15.7$, $3.6 \mathrm{~Hz}, \mathrm{dd}), 0.06(9 \mathrm{H}, \mathrm{s}) .{ }^{13} \mathrm{C} \mathrm{NMR}\left(100 \mathrm{MHz}, \mathrm{CDCl}_{3}\right) \delta-0.5(3 \mathrm{C}), 10.7,20.2,21.7,23.7 ; 29.6$ (3C), 30.8, 33.6, 36.5, 40.0, 42.7, 43.0, 47.3, 82.8. Anal. Calc. for $\mathrm{C}_{18} \mathrm{H}_{36} \mathrm{OSi}$ : C 72.90, H 12.24. Found: C 72.94, H 12.27. MSCI NH 3 m/z (rel. int.) : 279 ([M- $\left.\left.\mathrm{H}_{2} \mathrm{O}\right]^{+}, 100\right), 314$ ([M-NH$\left.]^{+}, 10\right)$.

1-(-3,3-Dimethyl-(Z)-1-butenyl-1-trimethylsilylmethyl)-2,2-dimethyl-1-cyclohexanol (2j). Colorless oil. $\mathrm{Rf}=0.40$ (85/15 : petroleum ether $\left./ \mathrm{CH}_{2} \mathrm{Cl}_{2}\right)$. IR (film) : 3620, 2960, 1630, 1460, 1240, 1150, $850 \mathrm{~cm}^{-1} .{ }^{1} \mathrm{H}$ NMR (400 MHz, $\left.\mathrm{CDCl}_{3}\right) \oint 5.05(1 \mathrm{H}, \mathrm{s}), 2.10-1.99(1 \mathrm{H}, \mathrm{m}), 1.96-1.66$ $\left(2 \mathrm{H}, \mathrm{m}_{\mathrm{AB}}\right), 1.61-1.36(6 \mathrm{H}, \mathrm{m}), 1.14(9 \mathrm{H}, \mathrm{s}), 1.10-1.21(1 \mathrm{H}, \mathrm{m}), 0.97(3 \mathrm{H}, \mathrm{s}), 0.88(3 \mathrm{H}, \mathrm{s}), 0.07$ $(9 \mathrm{H}, \mathrm{s}) .{ }^{13} \mathrm{C} \mathrm{NMR}\left(100 \mathrm{MHz}, \mathrm{CDCl}_{3}\right) \delta 0.0$ (3C), 19.9, 20.7, 21.4, 23.7, 26.0, 31.1 (3C), 31.6, 33.1, 36.5, 38.1, 78.0, 132.6, 140.7 Anal. Calc. for $\mathrm{C}_{18} \mathrm{H}_{36} \mathrm{OSi}$ : C 72.90, H 12.24. Found: C 73.05, H 12.31 .

2-tert-Butyl-3-deutero-3-trimethylsilylmethyl-7a-methylperhydro-3a-indenol (3jD). Colorless oil. $\mathrm{Rf}=0.24$ (85/15 : petroleum ether $/ \mathrm{CH}_{2} \mathrm{Cl}_{2}$ ). IR (film) : 3500, 2960, 1460, 1340, 1240, 1070, $830 \mathrm{~cm}^{-1} .{ }^{1} \mathrm{H}$ NMR $\left(400 \mathrm{MHz} \mathrm{CDCl}_{3}\right) \delta 2.04(1 \mathrm{H}, J=9.7 \mathrm{~Hz}, \mathrm{t}), 1.65-1.25(10 \mathrm{H}$, m), $1.04(3 \mathrm{H}, \mathrm{s}), 1.00(1 \mathrm{H}, J=16.3 \mathrm{~Hz}, \mathrm{~d}), 0.97(9 \mathrm{H}, \mathrm{s}), 0.55(1 \mathrm{H}, J=16.3 \mathrm{~Hz}, \mathrm{~d}), 0.06(9 \mathrm{H}, \mathrm{s})$.

${ }^{13} \mathrm{C}$ NMR (100 MHz, $\mathrm{CDCl}_{3}$ ) $\delta-0.5$ (3C), 10.6, 20.2, 21.7, 23.7, 29.7 (3C), 30.7, 33.6, 36.6, 39.6

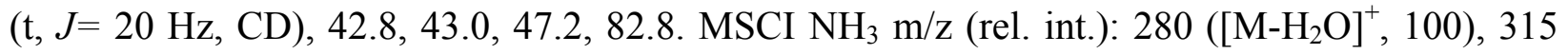
$\left(\left[\mathrm{M}-\mathrm{NH}_{4}\right]^{+}, 10\right)$.

1-(3,3-Dimethyl-(Z)-1-butenyl-1-trimethylsilylmethyl)-2,2-dimethyl-(3 and 5-deutero)-1cyclohexanol (2jD). Colorless oil. $\mathrm{Rf}=0.40$ (85/15: petroleum ether/ $\left.\mathrm{CH}_{2} \mathrm{Cl}_{2}\right)$. IR (film) : 3620 , 2950, 1460, 1240, 1150, $850 \mathrm{~cm}^{-1} .{ }^{2} \mathrm{H} \mathrm{NMR}\left(350 \mathrm{MHz}, \mathrm{CHCl}_{3}+20 \% \mathrm{CDCl}_{3}\right) \delta 1.56(79 \%)$, 1.09 (21\%). ${ }^{13} \mathrm{C}$ NMR (100 MHz, $\left.\mathrm{CDCl}_{3}\right) \delta 0.0$ (3C), 19.9, 20.7, 21.4 (residual (M)), 21.0 (t, $J=$ $20 \mathrm{~Hz}, \mathrm{CHD}(\mathrm{M})$ ), 23.7, 26.0, 31.1 (3C), 31.6, 33.1, 36.1 (t, $J=20 \mathrm{~Hz}, \mathrm{CHD}(\mathrm{m})$ ), 36.5 (residual (m)), 38.1, 78.0, 132.6, 140.7 . 


\section{Acknowledgements}

S.B. thanks Glaxo-Wellcome for a grant. The authors are grateful to Isabelle Correia (UPMC) for nOe measurements and to Dr. C. Chatgilialoglu (CNR Bologna) for helpful discussions. CNRS, UPMC and IUF are acknowledged for financial support.

\section{References and Notes}

1. For a review, see: (a) Ishibashi, H.; Sato, T.; Ikeda, M. Synthesis 2002, 695. (b) Ishibashi, H. Chem. Rec. 2006, 6, 23. (c) For a general review of radical cascade reaction, see: Albert, M.; Fensterbank, L.; Lacôte, E.; Malacria, M. Top. Curr. Chem. 2006, 264, 22647.

2. Baldwin, J. E. J. Chem. Soc., Chem. Commun. 1976, 734.

3. For a recent example, see: Bommezijn, S.; Gonzalez Martin, C.; Kennedy, A. R.; Lizos, D.; Murphy, J. A. Org. Lett. 2001, 3, 3405, see also references therein.

4. For recent examples, see : (a) Clive, D. L. J.; Yang, W.; MacDonald, A. C.; Wang, Z.; Cantin, M. J. Org. Chem. 2001, 66, 14966, see also references therein. (b) Fuwa, H.; Sasaki, M. Org. Lett. 2007, 9, 3347. (c) Jessop, C. M.; Parson, A. F.; Routledge, A.; Irvine, D. J. Eur. J. Org. Chem. 2006, 1547. (d) Marchand, P.; Gulea, M.; Masson, S.; Saquet, M.; Collignon, N. Org. Lett. 2000, 2, 3757.

5. (a) Chatgilialoglu, C.; Ferreri, C.; Guerra, M.; Timokhin, V.; Froudakis, G.; Gimisis, T. J. Am. Chem. Soc. 2002, 124, 10765. (b) For a review dealing with "the gem-disubstitutent effect" see: Jung, M. E.; Piizzi, G. Chem. Rev. 2005, 105, 1735.

6. (a) Fensterbank, L.; Malacria, M.; McN. Sieburth, S. Synthesis 1997, 8, 813. (b) Bogen, S.; Fensterbank, L.; Malacria, M. J. Am. Chem. Soc. 1997, 119, 5037. (c) Bogen, S.; Fensterbank, L.; Malacria, M. J. Org. Chem. 1999, 64, 819. (d) Fensterbank, L.; Dhimane, A.-L.; Wu, S.; Lacote, E.; Bogen, S.; Malacria, M. Tetrahedron 1996, 52, 11405. (e) Gulea, M.; Lopez-Romero, J. M.; Fensterbank, L.; Malacria, M. Org. Lett. 2000, 2, 2591. (f) Mainetti, E.; Fensterbank, L.; Malacria, M. Synlett 2002, 923. (g) see also Maddess, M. L.; Mainetti, E.; Harrak, Y.; Brancour, C.; Devin, P.; Dhimane, A.-L.; Fensterbank, L.; Malacria, M. Chem. Commun. 2007, 936. (h) Gulea, M.; Lopez-Romero, J. M.; Fensterbank, L.; Malacria, M. Org. Lett. 2000, 2, 2591.

7. Bogen, S.; Malacria, M. J. Am. Chem. Soc. 1996, 118, 3992.

8. The relative stereochemistry was confirmed by an X-ray crystallographic determination on cyclopentanediol derivative 31 .

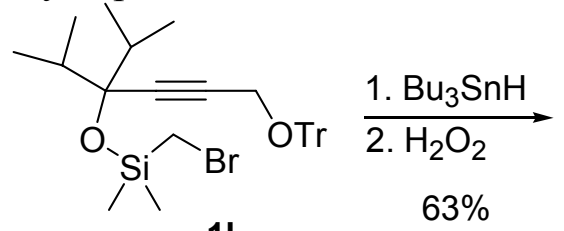

11

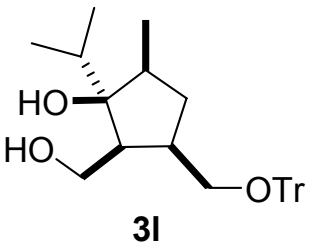

31 
9. In the case of vinyl silane, no aldehyde was isolated. Bogen, S.; Gulea, M.; Fensterbank, L.; Malacria, M. J. Org. Chem. 1999, 64, 4920.

10. For a study on H-transfers from an alkyl radical leading to an alkyl radical, see Gross, A.; Fensterbank, L.; Bogen, S.; Thouvenot, R.; Malacria, M. Tetrahedron 1997, 53, 13797.

11. For an example of diquinane synthesis from bromomethyldimethylsilyl propargyl ethers, see: Journet, M.; Smadja, W.; Malacria, M. Synlett 1990, 320. 